\title{
Nitrate Removal from Ground Water: A Review
}

\author{
ARCHNA*, SURINDER K. SHARMA ${ }^{* *}$, AND RANBIR CHANDER SOBTI ${ }^{* * *}$ \\ *Department of Chemical Engineering \\ M S Ramaiah Institute of Technology, Bangalore-560054, India \\ ** Department of Chemical Engineering, Panjab University, Chandigarh, India \\ ${ }^{* * *}$ Department of Biotechnology, Panjab University, Chandigarh, India \\ archna_71@yahoo.com
}

Received 1 March 2011; Accepted 27 April 2011

\begin{abstract}
Nitrate contamination of ground water resources has increased in Asia, Europe, United States, and various other parts of the world. This trend has raised concern as nitrates cause methemoglobinemia and cancer. Several treatment processes can remove nitrates from water with varying degrees of efficiency, cost, and ease of operation. Available technical data, experience, and economics indicate that biological denitrification is more acceptable for nitrate removal than reverse osmosis and ion exchange. This paper reviews the developments in the field of nitrate removal processes which can be effectively used for denitrifying ground water as well as industrial water.
\end{abstract}

Keywords: Biological denitrification, IEMB - Ion exchange membrane bioreactor, MBR- Membrane bioreactor, ED - Electrodialysis.

\section{Introduction}

Nitrate contamination of ground water in various parts of the world has increased alarmingly. Nitrate levels have been increasing in drinking water supplies in most countries $^{1-5}$. Environmental protection agency (EPA) in 1990 indicated that 250,000 water supply sources had maximum contaminant levels (MCL) for nitrate ${ }^{6}$. The World Health Organization (WHO), 2004 found that $30 \%$ of the 2,000 sources surveyed in world had more than $24 \mathrm{mg} / \mathrm{L}$.

Nitrate levels have increased due to increased usage of nitrogenous fertilizers, changes in land-use patterns and increased recycling of domestic wastewater ${ }^{7-8}$. While nitrate is considered to be relatively non-toxic to adults, in infants, $\mathrm{NO}_{3}{ }^{-}$is reduced to $\mathrm{NO}_{2}{ }^{-}$; which combines with hemoglobin in the blood to form methamoglobin and leads to a condition commonly known as "blue baby syndrome." Health and Welfare World Guidelines ${ }^{9}$ had established a limit of $45 \mathrm{mgNO}_{3}^{-} / \mathrm{L}$.

Many technologies for the removal of nitrate from water have been adopted based on scientific developments. A brief overview of all techniques is presented in this paper. 


\section{Treatment Techniques}

Nitrate is a stable and highly soluble ion with low potential for coprecipitation or adsorption. Thus conventional treatment technologies cannot be used. This paper reviews various techniques in terms of their effectiveness, ease of operation and cost.

\section{Chemical denitrification}

Nitrate reduction can be induced under basic $\mathrm{pH}$ according to the following reaction ${ }^{10}$ :

$$
3 \mathrm{NO}_{3}{ }^{-}+8 \mathrm{Fe}(\mathrm{OH})_{2}+6 \mathrm{H}_{2} \mathrm{O} \rightarrow \mathrm{NH}_{3}+8 \mathrm{Fe}(\mathrm{OH})_{3}+\mathrm{OH}^{-}
$$

Experimental results showed that a $\mathrm{Fe}: \mathrm{NO}_{3}{ }^{-}$ratio of about 15: 1 was required in the presence of copper catalyst for the reaction to proceed. This process generated a large quantity of iron sludge and formed ammonia that requires removal by air stripping. The process was associated with high costs.

In chemical denitrification by powdered aluminum ammonia was found to be the principal reaction product $(60-95 \%)$ at $\mathrm{pH}$ of 10.25 , which was removed by air stripping ${ }^{11-12}$. The denitrification was explained on the basis of the following reactions:

$$
\begin{gathered}
3 \mathrm{NO}_{3}^{-}+2 \mathrm{Al}+3 \mathrm{H}_{2} \mathrm{O} \rightarrow 3 \mathrm{NO}_{2}^{-}+2 \mathrm{Al}(\mathrm{OH})_{3} \\
\mathrm{NO}_{2}^{-}+2 \mathrm{~A} 1+5 \mathrm{H}_{2} \mathrm{O} \rightarrow \mathrm{NH}_{3}+2 \mathrm{Al}(\mathrm{OH})_{3}+\mathrm{OH}^{-} \\
2 \mathrm{NO}_{2}^{-}+2 \mathrm{Al}+4 \mathrm{H}_{2} \mathrm{O} \rightarrow \mathrm{N}_{2}+2 \mathrm{Al}(\mathrm{OH})_{3}+2 \mathrm{OH}^{-}
\end{gathered}
$$

Aluminum reacted with water as per the following equation:

$$
2 \mathrm{~A} 1+6 \mathrm{H}_{2} \mathrm{O} \rightarrow 2 \mathrm{Al}(\mathrm{OH})_{3}+3 \mathrm{H}_{2}
$$

It was shown that $1.16 \mathrm{~g}$ of aluminum was required for the reduction of $1 \mathrm{~g}$ of nitrate. Catalytic reduction of nitrate with $\mathrm{Pd}$ and/Cu catalysts was another removal technique ${ }^{13}$. It was found that $\mathrm{Pd}-\mathrm{Cu}$ combined catalysts at a ratio of 4 can maximize the nitrate reduction into nitrogen; above $80 \%$ total nitrate removal efficiency was realized. $84 \%$ denitrification efficiency was achieved at ambient temperature and pressure using zero-valent magnesium $(\mathrm{Mg}(0))^{14}$ for $\mathrm{Mg}(0): \mathrm{NO}_{3}{ }^{-}-\mathrm{N}$ molar ratio of 5.8 and $\mathrm{pH}$ of 2 .

\section{Reverse osmosis for denitrification}

Nitrates could be removed by reverse osmosis cells under pressures ranging from 300 to 1,500 psi to reverse the normal osmotic flow of water. Membranes used were made of cellulose acetate, polyamides and composite materials. Problems associated with reverse osmosis membranes included fouling, compaction and deterioration with time. These problems resulted from deposition of soluble materials, organic matter, suspended and colloidal particles, and other contaminants, $\mathrm{pH}$ variations and chlorine exposure; thus the reverse osmosis process required pretreatment.

A 15-gpm spiral wound cellulose acetate reverse osmosis system was tested for 1,000 h and up to $65 \%$ nitrate separation was observed for influent $\mathrm{NO}_{3}{ }^{-}$concentrations ranging from 18 to $25 \mathrm{mg} / \mathrm{L}^{15}$. 
Reverse osmosis using both polyamide and cellulose triacetate membranes were tested and sulfuric acid and sodium hexametaphosphate were added to feed water to prevent scaling. Polyamide membranes were more effective than cellulose triacetate membranes ${ }^{16}$.

A pilot plant using spiral wound modules with composite membranes was operated with a $2 \mathrm{~m}^{3} / \mathrm{h}$ capacity, at an operating pressure of 14 bar. Influent pretreatment consisted of passing the water through $5 \mu \mathrm{m}$ cartridge filters and acid dosing to avoid scaling. The results showed high levels of denitrification ${ }^{17}$.

\section{Electrodialysis (ED) for denitrification}

In ED ions are transferred through membranes from a less concentrated to a concentrated solution by application of direct electric current. ED treated the water by selective removal of undesirable ions through a semi permeable membrane. An electrodialysis system required a supply of pressurized water [50-75 psi (345-578 $\mathrm{kPa})]$ with pretreatment.

In the electrodialysis reversal (EDR) process, the polarity of the electrodes was reversed two to four times an hour to alter the direction of ion movement. The EDR process reduced scaling and chemical usage compared with conventional ED and was used for the production of drinking water from nitrate rich water. The nitrate removal efficiency of ED and RO processes was almost the same ${ }^{18}$.

A selective nitrate removal process was developed, NitRem, based on $\mathrm{ED}^{19}$. The process was effective in reducing nitrate concentrations from $50 \mathrm{mg} / \mathrm{L}$ or more to less than $25 \mathrm{mg} / \mathrm{L}$. An attractive feature of the process was that it included the removal of nitrate without the addition of any chemicals.

It was observed that for nitrate reduction from 100 to $50 \mathrm{mg} \mathrm{NO}_{3}{ }^{-} / \mathrm{L}$ the costs of EDR and RO were about the same ${ }^{18}$. It was expected capital and maintenance cost of membrane filtration to reduce with time ${ }^{20}$.

\section{Catalytic denitrification}

A catalytic process was developed for the removal of nitrite and nitrate from water ${ }^{21}$. Palladium - alumina catalysts were effective in reducing nitrite to nitrogen (98\%) and ammonia in the presence of hydrogen. The lead (5\%), copper $(1.25 \%), \mathrm{Al}_{2} \mathrm{O}_{3}$, catalyst were found to completely remove nitrate from water having an initial nitrate concentration of $100 \mathrm{mg} / \mathrm{L}$. The reaction was completed in $50 \mathrm{~min}$. The process operated effectively at a temperature of $10^{\circ} \mathrm{C}$ and $\mathrm{pH}$ 6-8.

\section{Electrocatalytic reduction for denitrification}

An electrocatalytic reduction process was used to remove $\mathrm{NO}_{3}{ }^{-}$from groundwater ${ }^{22}$. A commercially available carbon cloth with a $30 \%$ surface coated $\mathrm{Rh}$ (rhodium) $\left(1 \mu \mathrm{g} \mathrm{cm}^{-1}\right)$ was tested at an applied potential of $-1.5 \mathrm{~V}$ versus standard calomel electrode (SCE) with a $\mathrm{Pt}$ auxiliary electrode. The results suggested that electrocatalysis reduced $\mathrm{NO}_{3}{ }^{-}$ concentrations in groundwater from 73 to $39 \mathrm{mg} / \mathrm{L}$ on a timescale range of $40-60 \mathrm{~min}$.

\section{Ion exchange process}

The ion exchange process involved passage of nitrate water through a resin bed containing strong base anion (SBA) exchange resins on which nitrate ions were exchanged for chloride or bicarbonate ions until the resin exhausted. The exhausted resin was regenerated using a concentrated solution of sodium chloride or sodium bicarbonate ${ }^{23}$.

Fifteen ion exchange plants used in the united states ${ }^{24}$ reduced nitrate from 18 to $6.8 \mathrm{mg} / \mathrm{L}^{25}$. Addition of bentonite clay to the backwash water helped restore the resin, which was regenerated with $1 \mathrm{~N} \mathrm{NaOH}$ and $\mathrm{HCl}$. Nitrate removal capacity of the resins was reduced by 
Silica and iron precipitates ${ }^{26}$. An ion exchange process was tested for the removal of nitrate from ground water containing $16-23 \mathrm{mg} \mathrm{NO}_{3}^{-} / \mathrm{L}$ at flow rates of up to $31.5 \mathrm{~L} / \mathrm{m}^{2} . \mathrm{s}^{27}$.

Treatment of sulfate water with resins is difficult as the nitrate removal capacity of the resin is reduced by the sulfate ions. It was observed that sulfate selectivity was reduced by increasing the distance between ion-exchange sites and nitrate selectivity can be increased by increasing the matrix and functional group hydrophobicity ${ }^{28}$. Triethyl amine resins showed an increase in the bed life by $62 \%$ when treating water containing $1.5 \mathrm{meq} / \mathrm{L}$ nitrate and $6.5 \mathrm{meq} / \mathrm{L}$ sulfate ${ }^{27}$. Regenerant usage decreased by $25-50 \%$, thus the operating cost of the ion exchange process reduced.

The $0.043 \mathrm{~m}^{3} / \mathrm{s}$ ion exchange plant in California (USA) used a non-nitrate-selective resin, which was regenerated using a saturated brine solution ${ }^{29}$. The total treatment cost was reported to be 24.2 cents/1,000 gal. The energy requirements of the plant were $0.244 \mathrm{kWh}$ per $1,000 \mathrm{gal}^{27}$.

A pilot-scale study was conducted to evaluate nitrate removal from drinking water by ion exchange, reverse osmosis (RO) and electrodialysis (ED) ${ }^{16}$. The raw water contained $18-25 \mathrm{mg} / \mathrm{L}, 43 \mathrm{mg} / \mathrm{L}$ sulfate and $530 \mathrm{mg} / \mathrm{L}$ total dissolved solids (TDS). All processes were able to reduce nitrate concentration below $10 \mathrm{mg} / \mathrm{L}$.

Ion exchange process was found to be five times more economical in comparison to RO process $^{29}$. A process was developed in which regeneration and exhaustion were performed in the same direction and reduced nitrate concentrations from 15.8 to $5.7 \mathrm{mg} / \mathrm{L}^{30}$. The Carbon dioxide regenerated ion exchange resins (CARIX) process for removing nitrate, sulfate, and hardness from water was based on ion exchange principles ${ }^{31-33}$. The exhausted exchange resins were regenerated through contact with a concentrated carbon dioxide solution. A CARIX pilot plant $\left(0.047 \mathrm{~m}^{3} / \mathrm{s}\right)$ was constructed in Germany which was effective in reducing nitrate concentrations from $90 \mathrm{mg} / \mathrm{L}$ to less than $5.7 \mathrm{mg} / \mathrm{L}$. The consumption of carbon dioxide amounted to $0.35 \mathrm{~kg} / \mathrm{m}^{3}$ of treated water.

\section{Denitrification using a membrane bioreactor}

Immersed heterotrophic membrane bioreactor (MBR) produced high quality product water ${ }^{34}$ when $\mathrm{NO}_{3}{ }^{-}$contaminated water was made to flow through the lumen of tubular microporous membranes. $\mathrm{NO}_{3}{ }^{-}$diffused through the membrane pores. Denitrification took place on the shell side of the membranes ${ }^{35}$. The MBR achieved over $99 \% \mathrm{NO}_{3}{ }^{-}$removal at an influent concentration of $200 \mathrm{mg} \mathrm{NO}_{3}^{-} / \mathrm{L}$.

\section{Combined ion exchange \& membrane bioreactor for denitrification}

The IEMB concept combines dialysis and simultaneous biological degradation of nitrate in small concentrations ${ }^{36-37}$. The IEMB process operated with hydraulic retention times ranging from 1.4 to $8.3 \mathrm{~h}$ in the water compartment, proved to remove nitrates effectively, while preserving the water composition with respect to other ions, thus avoiding secondary contamination of the treated water.

\section{Denitrification using nanofiltration}

During the last decade, nano filtration (NF) made a breakthrough in drinking water production for the removal of nitrate ${ }^{38}$. For the removal of nitrates the membranes NF70, NF45, UTC-20, and UTC-60 have been experimentally studied. The results showed that only a small fraction of nitrate was removed for most membranes, except for NF70 where a $76 \%$ nitrate removal was obtained. 


\section{Biological denitrification}

Many bacteria belonging to different genera can grow anaerobically by reducing ionic nitrogenous oxides to gaseous products. Nitrates or nitrites served as the terminal electron acceptors instead of oxygen and resulted in generation of $\mathrm{ATP}^{39}$. Such denitrification was dissimilatory nitrate reduction ${ }^{40}$. When electrons are transferred from the donor to the acceptor, the organism gains energy which was applied for the synthesis of a new cell mass and the maintenance of the existing cellmass. The enzymes associated with denitrification are synthesized under anaerobic or partially aerobic conditions ${ }^{41}$. Nitrate reduction to nitrogen gas occurred as:

$$
\mathrm{NO}_{3}{ }^{-} \rightarrow \mathrm{NO}_{2}{ }^{-} \rightarrow \mathrm{NO} \rightarrow \mathrm{N}_{2} \mathrm{O} \rightarrow \mathrm{N}_{2}
$$

Each step was catalyzed by an enzyme system. Dissimilatory reduction of nitrate to nitrite was important for most bacteria, since the process involved energy conservation by increased substrate level phosphorylation reaction ${ }^{42}$.

Since denitrification was a respiratory process, an oxidisable substrate was needed as an energy source. Limitation of biological denitrification was possible bacterial contamination and presence of residual organics ${ }^{43-47}$.

\section{Heterotrophic denitrification}

Most denitrifying bacteria are heterotrophic and utilize complex organic substances as oxidisable substrates such as methanol, ethanol, methane, carbon monoxide, and acetic $\operatorname{acid}^{48-52}$ for the conversion of nitrate to nitrogen. The cell formula $\mathrm{C}_{5} \mathrm{H}_{7} \mathrm{NO}_{2}$ suggested by Hoover was used and the stoichiometric of various organic carbon substrates required for nitrate dissimilation are as listed in Table $1^{53}$.

Table 1. Stoichiometric relationships of heterotrophic denitrification with various carbonaceous substrates ${ }^{54-62}$.

\begin{tabular}{|c|c|c|}
\hline S.N. & Substrate & Stoichiometric equation \\
\hline 1. & Ethanol & $\begin{array}{l}* 5 \mathrm{C}_{2} \mathrm{H}_{5} \mathrm{OH}+12 \mathrm{NO}_{3}^{-} \rightarrow 10 \mathrm{HCO}_{3}^{-}+2 \mathrm{OH}^{-}+9 \mathrm{H}_{2} \mathrm{O}+6 \mathrm{~N}_{2} \\
* 0.613 \mathrm{C}_{2} \mathrm{H}_{5} \mathrm{OH}+\mathrm{NO}_{2}^{-} \rightarrow 0.102 \mathrm{C}_{5} \mathrm{H}_{7} \mathrm{NO}_{2}+0.714 \mathrm{CO}_{2}+ \\
0.286 \mathrm{OH}^{-}+0.980 \mathrm{H}_{2} \mathrm{O}+0.449 \mathrm{~N}_{2}\end{array}$ \\
\hline 2. & Acetic acid & $\begin{array}{l}* 5 \mathrm{CH}_{3} \mathrm{COOH}+8 \mathrm{NO}_{3}^{-} \rightarrow 8 \mathrm{HCO}_{3}^{-}+2 \mathrm{CO}_{2}+6 \mathrm{H}_{2} \mathrm{O}+\mathrm{N}_{2} \\
* 0.819 \mathrm{CH}_{3} \mathrm{COOH}+\mathrm{NO}_{3}^{-} \rightarrow 0.068 \mathrm{C}_{5} \mathrm{H}_{7} \mathrm{NO}_{2}+\mathrm{HCO}_{3}^{-}+0.301 \\
\mathrm{CO}_{2}+0.902 \mathrm{H}_{2} \mathrm{O}+0.466 \mathrm{~N}_{2}\end{array}$ \\
\hline 3. & Propanol & $0.278 \mathrm{C}_{3} \mathrm{H}_{7} \mathrm{OH}+\mathrm{NO}_{3}^{-} \rightarrow 0.5 \mathrm{~N}_{2}+0.833 \mathrm{CO}_{2}+0.611 \mathrm{H}_{2} \mathrm{O}+\mathrm{N}_{2}$ \\
\hline 4. & Cellulose & $\begin{array}{l}5\left(\mathrm{C}_{6} \mathrm{H}_{10} \mathrm{O}_{5}\right)_{\mathrm{n}}+24 \mathrm{n} \mathrm{NO}_{3}^{-} \rightarrow 6 \mathrm{nCO}_{2}+13 \mathrm{n} \mathrm{H}_{2} \mathrm{O}+12 \mathrm{n} \mathrm{N}_{2}+24 \mathrm{n} \\
\mathrm{HCO}_{3}^{-}\end{array}$ \\
\hline 5. & Butanol & $\begin{array}{l}0.208 \mathrm{C}_{4} \mathrm{H}_{9} \mathrm{OH}+\mathrm{NO}_{3}^{-} \rightarrow 0.5 \mathrm{~N}_{2}+0.833 \mathrm{CO}_{2}+0.542 \mathrm{H}_{2} \mathrm{O}+ \\
\mathrm{OH}^{-}\end{array}$ \\
\hline 6. & $\begin{array}{c}\text { Aromatic } \\
\text { hydrocarbon }\end{array}$ & $\mathrm{C}_{61} \mathrm{H}_{67}+62.2 \mathrm{H}^{+}+62.2 \mathrm{NO}_{3}^{-} \rightarrow 31.1 \mathrm{~N}_{2}+61 \mathrm{CO}_{2}+64.6 \mathrm{H}_{2} \mathrm{O}$ \\
\hline 7. & Organic matter & $\begin{array}{l}\mathrm{C}_{5} \mathrm{H}_{9} \mathrm{NO}+3.36 \mathrm{NO}_{3}^{-}+3.92 \mathrm{H}^{+} \rightarrow 1.68 \mathrm{~N}_{2}+0.36 \mathrm{C}_{5} \mathrm{H}_{7} \mathrm{NO}_{2}+ \\
3.2 \mathrm{CO}_{2}+3.92 \mathrm{H}_{2} \mathrm{O}+0.64 \mathrm{NH}_{4}^{+}\end{array}$ \\
\hline 8. & Methane & $5 \mathrm{CH}_{4}+8 \mathrm{NO}_{3}^{-}+8 \mathrm{H}^{+} \rightarrow 4 \mathrm{~N}_{2}+5 \mathrm{CO}_{2}+14 \mathrm{H}_{2} \mathrm{O}$ \\
\hline 9. & Glucose & $\begin{array}{l}\mathrm{C}_{6} \mathrm{H}_{12} \mathrm{O}_{6}+2.8 \mathrm{NO}_{3}^{-}+0.5 \mathrm{NH}_{4}^{+}+2.3 \mathrm{H}^{+} \rightarrow 0.5 \mathrm{C}_{5} \mathrm{H}_{7} \mathrm{NO}_{2}+1.4 \\
\mathrm{~N}_{2}+3.5 \mathrm{CO}_{2}+6.4 \mathrm{H}_{2} \mathrm{O}\end{array}$ \\
\hline
\end{tabular}


Pilot scale studies using heterotrophic denitrification were conducted using packed and fluidized columns ${ }^{63}$. The reactors required a start-up period of two weeks to establish sufficient bacterial populations. The highest denitrification rate per unit reactor volume was observed for the fluidized sand bed $\left(160 \mathrm{~g} \mathrm{~N} / \mathrm{m}^{3} . \mathrm{h}\right.$ at $\left.10^{\circ} \mathrm{C}\right)$ and lowest for the packed bed reactors $\left(12 \mathrm{~g} \mathrm{~N} / \mathrm{m}^{3}\right.$.h at $\left.10^{\circ} \mathrm{C}\right)$. Nitrate concentrations were reduced to approximately $45 \mathrm{mg} / \mathrm{L}^{64-65}$.

Denitrification by immobilized Pseudomonas denitrificans cells was studied using a sodium alginate polymer and ethanol as the carbon source ${ }^{66}$. The nitrate concentration reduced from 104 to $0.1 \mathrm{mg} / \mathrm{L}$. The limitations of the process being that the low rate of diffusion of substrate and reaction products through the alginate matrix and the short life span of the alginate matrix. To overcome these problems ${ }^{67-68}$ a membrane-immobilized biofilm reactor was developed in which denitrifying bacteria and carbon energy source were segregated from the water to be treated.

\section{Autotrophic denitrification}

Some bacteria from the genera Paracoccus, Thiobacillus, Thiosphaera and others can accomplish denitrification autotrophically using hydrogen or various reduced sulfur compounds such as $\mathrm{S}^{0}, \mathrm{~S}^{2-}, \mathrm{S}_{2} \mathrm{O}_{3}{ }^{2-}, \mathrm{S}_{4} \mathrm{O}_{2}{ }^{2-}$, or $\mathrm{SO}_{3}{ }^{2-}$ as energy sources. Bacteria from the genera Ferrobacillus, Gallionella, Leptothrix and Sphaerotillus can utilize ferrous iron as an energy source for autotrophic denitrification. Under autotrophic growth conditions, carbon dioxide or bicarbonate was used as carbon source for microbial cell synthesis. Stoichiometric equations of autotrophic denitrification with various energy sources are listed in Table 2.

Table 2. Stoichiometric relationships of autotrophic denitrification with various electron donors.

\begin{tabular}{cll}
\hline S.N. & $\begin{array}{c}\text { Electron } \\
\text { donor }\end{array}$ & \multicolumn{1}{c}{ Stoichiometric equation } \\
\hline 1. & Hydrogen & $2 \mathrm{NO}_{3}{ }^{-}+5 \mathrm{H}_{2} \rightarrow \mathrm{N}_{2}+4 \mathrm{H}_{2} \mathrm{O}+2 \mathrm{OH}^{-}$ \\
2. & Ferrous iron & $\mathrm{NO}_{3}{ }^{-}+5 \mathrm{Fe}^{2-} \rightarrow 0.5 \mathrm{~N}_{2}+5 \mathrm{Fe}(\mathrm{OH})_{2}+9 \mathrm{H}^{+}$ \\
3. & Sulfide & $14 \mathrm{NO}_{3}{ }^{-}+5 \mathrm{FeS}_{2}+4 \mathrm{H}^{+} \rightarrow 7 \mathrm{~N}_{2}+10 \mathrm{SO}_{4}^{2-}+5 \mathrm{Fe}^{2+}+2 \mathrm{H}_{2} \mathrm{O}$ \\
4. & Thiosulfate & $* 8 \mathrm{NO}_{3}{ }^{-}+5 \mathrm{~S}_{2} \mathrm{O}_{3}{ }^{2-}+\mathrm{H}_{2} \mathrm{O} \rightarrow 4 \mathrm{~N}_{2}+10 \mathrm{SO}_{4}{ }^{2-}+2 \mathrm{H}^{+}$ \\
& & $* 0.141 \mathrm{NO}_{3}{ }^{-}+0.125 \mathrm{~S}_{2} \mathrm{O}_{3}{ }^{2-}+0.0643 \mathrm{CO}_{2}+0.1 \mathrm{H}_{2} \mathrm{O} \rightarrow 0.0129$ \\
& & $\mathrm{C}_{5} \mathrm{H}_{7} \mathrm{NO}_{2}+0.064 \mathrm{~N}_{2}+0.25 \mathrm{SO}_{4}{ }^{2-}+0.109 \mathrm{H}^{+}$ \\
5. & Elemental & $10 \mathrm{NO}_{3}^{-}+11 \mathrm{~S}^{\circ}+4.1 \mathrm{HCO}_{3}^{-}+0.5 \mathrm{CO}_{2}+1.71 \mathrm{NH}_{4}++2.54 \mathrm{H}_{2} \mathrm{O} \rightarrow$ \\
& sulfur & $0.92 \mathrm{C}_{5} \mathrm{H}_{7} \mathrm{NO}_{2}+11 \mathrm{SO}_{4}{ }^{2-}+5.4 \mathrm{~N}_{2}+9.62 \mathrm{H}^{+}$ \\
\hline
\end{tabular}

Thiobacillus denitrificans was used to reduce nitrate concentrations from 24 to $1 \mathrm{mg} / \mathrm{L}$ in packed bed reactors using elemental sulfur as an electron source ${ }^{69}$. Schippers described denitrification using sulfur limestone filtration ${ }^{70}$. Lewandowski encapsulated autotrophic denitrifiers in calcium alginate beads containing sulfur and calcium carbonate for autotrophic denitrification $^{71}$. Nitrate concentrations were reduced from 27 to $6 \mathrm{mg} / \mathrm{L}$ in seven hours.

A process known as DENITROPUR was developed using hydrogenotrophic denitrification $^{72}$. The process does not require the post treatment that heterotrophic denitrification requires. The reproduction rate of autotrophic bacteria is low, therefore, less biomass sludge was generated.

\section{Conclusion}

The three treatment processes that have been applied full-scale for nitrate removal include ion exchange, biological de-nitrification and reverse osmosis. The other methods discussed have limited potential for full-scale application. The literature indicates wider application of heterotrophic biological denitrification in comparison with autotrophic denitrification. The 
technical and economic feasibility of heterotrophic denitrification has been confirmed at full scale in some European countries. The autotrophic reaction rate is low, therefore reactors with large volumes are required to achieve sufficient residence time for denitrification, thus increasing capital costs.

Removal of nitrates from drinking water is an important and developing area of research. Technology development has occurred in this area, but further optimization of current technologies is required. Biological denitrification reactor operation in regard to microbiological characteristics of biologically denitrified water demands attention. RO and ED performance data for nitrate removal is limited and the impact of rapid advances in these technologies should be examined.

\section{References}

1. Faillat J P, J Hydrol., 1990, 113(1-4), 231-264.

2. Fried J J Bogardi I and Kuzelka R D, Eds., Springer-Verlag, Berlin, Germany, 1991, 3-11.

3. Dillon P J, Ragusa S R, Richardson S B, Bogardi and Kuzelka R D, Eds., SpringerVerlag, Berlin, Germany, 1991, 173-180.

4. Gillham R W, Nitrate contamination: exposure, consequence and control, Bogardi I Kuzelka R D, Eds., Springer-Verlag, Berlin, Germany, 1991, 181-198.

5. Nixon N, Water/ Engrg Mgmt., 1992, 139, 27-28.

6. Briskin J S, Chemical Engrg News, 1991, 46, 50-53.

7. Bouchard D C, Williams M K and Surampalli R Y, $J A W W A$., 1992, 84(9), 85-90.

8. Peña-Haro S, Llopis-Albert $\mathrm{C}$, Pulido-Velazquez $\mathrm{M}$ and Pulido-Velazquez $\mathrm{D}, J$ Hydrology., 2010, 392(3-4), 174-187.

9. WHO "Guidelines for Drinking-Water Quality" ( $3^{\text {rd }}$ Edn.,) World Health Organization, 2004.

10. Sova R J, "The chemical removal of nitrate from water supplies using ferrous sulfates and pickle liquor," MS thesis, Univ. of Nebraska at Lincoln, Lincoln, Nebr, 1986.

11. Murphy A P, Nature, 1991, 350, 223-225.

12. Luk G K and Au-Yeung W C, Adv Environ Res., 2002, 6(4), 441-453.

13. Zhang Y, Chen Y and Chen G,. Huan Jing Ke Xue., 2003, 24(4), 109-112.

14. Kumar M and Chakraborty S, J Hazard Matter., 2006, 135(1-3), 112-21.

15. Guter G A, EPA/600/S2-86/115, U.S. Envir. Protection Agency (EPA), Cincinnati, Ohio, 1987a.

16. Clifford D, Lin C, Horng L and Boegel J, EPA/600/52-86/107, U.S. Envir. Protection Agency (EPA), Cincinnati, Ohio, 1987.

17. Rautenbach R, Kopp W, Hellekes R, Peter R and van Opbergen G, Aqua, 1986, 5, 279-282.

18. Rautenbach R, Kopp W, Van Opbergen G and Hellekes R, Desalination, 1987, 65, 241-258.

19. Miquel A E and Oldani M, "A newly developed process for nitrate removal from drinking water." Nitrate contamination: exposure, consequence and control, Bogardi I and Kuzelka R D, Eds., Springer-Verlag, Berlin, Germany, 1991, 385-394.

20. Adham S S, Jacangelo J G and Laine J, $J A W W A$, 1996, 88(5), 22-31.

21. Horold S, Tacke T and Vorlop K D, Envir Technol., 1993, 14(10), 931-939.

22. Peel J W, Reddy K J, Sullivan B P and Bowen J M, Water Res., 2003, 37(10), 2512-2519.

23. Kokufuta E, Shimohashi M and Nakamura I, Biotechnol Bioeng., 1988, 31, 382-384.

24. Clifford D and Liu X, $J$ AWWA, 1993, 85(4), 135-143.

25. Eliassen R, Wyckoff B M and Tonkin C D, $J A W W A$, 1995, 57(9), 1113-1122. 
26. Viraraghavan $\mathrm{T}$ and Rao G A K, "Treatment processes for nitrate removal from water." Proc, $42^{\text {nd }}$ Annu. Convention of the Western Canada Water and Wastewater Assn., Regina, Sask., Canada, 1990, 137-160.

27. Guter G A, EPA/600/S2-87/034, U.S. Envir. Protection Agency (EPA), Cincinnati, Ohio, 1987b.

28. Clifford D and Weber Jr J W, EPA-600/2-78-052, U.S. Envir Protection Agency (EPA), Cincinnati, Ohio, 1978.

29. Lauch R P and Guter G A, $J A W W A, 1986,78(5), 83-88$.

30. Philpot J. M and De Larminant G, Water Supply, 1988, 6, 45-50.

31. Hagen K, Holl W and Kretzschmar W, Aqua, 1986, 5, 275-278.

32. Holl W H and Kretzschmar W, Water Supply., 1988, 6, 51-55.

33. Wenli G, Wensheng H and Holl W H, Water SRT-Aqua., 1994, 43(2), 95-101.

34. McAdam E J and Simon J Judd, Water Res., 2007, 113, 231-264.

35. Sarina J. Ergas and David E. Rheinheimer, Water Res., 2004, 38(14-15), 3225-3232.

36. Boley A, Nuller W R and Haider G, Aquacult Eng., 2000, 22, 75-85.

37. Cristina T M, Svetlozar Velizarov, João G Crespo and Maria A M Reis, Water Res., 2006, 40(2), 231-240.

38. Bruggen Bart Van der and Carlo Vandecasteele, Environ Pollut., 2002, 122(3), 435-445.

39. Michalski W P and Nicholas D J D, Gen Microbiol., 1984, 130, 155-165.

40. Ritter W F and Eastburn R P, Environ Pollut Microbiol., 1988, 51, 49-61.

41. Synder S W Bazylinski D A and Hollocher T C, Appl Environ Microbiol., 1987, 53, 2045-2049.

42. Keith S M, MacFarlane G T and Herbert R A, Arch Microbiol., 1982, 132, 62-66.

43. Bouwer E J and Crowe P B, J AWWA, 1988, 80(9), 82-93.

44. Rittmann B E and Huck P M, CRC Critical Rev Envir Control, 1989, 19(2), 119-184.

45. Gayle B P, Boardman G D, Sherreard J H and Benoit R E, J Envir Engrg., ASCE, 1989, 115(5), 930-943.

46. Mateju V, Cizinska S, Krejci J and Janoch T, Enzyme Microbiol Technol., 1992, 14, 170-183.

47. Chung J and Bae W, Biodegrad., 2002, 13(3), 163-170.

48. Bockle R, Rohmann U and Wertz A, Aqua, 1986, 5, 286-287.

49. Lemoine D, Jouenne. T and Junter G.A, Biotechnol Lett., 1988, 13, 399-402.

50. Hunter W J, J Cont Hydrol., 2001, 53, 119-131.

51. Della Rocca C, Vincenzo Belgirono and Meric S, Water S A, 2005, 31(2), 229-236.

52. Della Rocca C, Ph.D. Thesis, University of Salerno, Engineering Faculty, 2005(a).

53. Hoover S R, Progress N Sew Envir Technol., 1992, 24, 306-312.

54. Lewandowski Z, Water Res., 1985, 19, 589-596.

55. Soares M I M, Belkin S and Abeliovich A, Water Res., 1989, 30, 965-971.

56. Soares M I M, Belkin S and Abeliovich A, Z Wasser-Abwasser-Forsch., 1991, 22, 20-24.

57. Volokita M, Belkin S, Abeliovich A and Soares M I M, Water Res., 1996a, 30(4), 965-971.

58. Volokita M, Abeliovich A and Soares M I M, Water Sci Technol., 1996b, 34(1-2), 379-385.

59. Soares M I M and Abeliovich A, Water Res., 1998, 32(12), 3790-3794.

60. Soares M I M, Water Air Soil Pollut., 2000, 123, 183-193.

61. Schipper L A and Vojvodic-Vukovic M, Ecol Eng., 2000, 14(3), 269-278.

62. Hunter W J, J Cont Hydrol., 2003, 66(1-2), 79-91.

63. Soares M I M, Brenner A, Yevzori A, Messalem R, Leroux Y and Abeliovich A, Water Sci Technol., 2000, 42(1-2), 353-359.

64. Dahab M F and Lee Y W, J Wat Pollut Contr Fed., 1988, 60(9), 1670-1674. 
65. Kappelhof J W N M, van der Hoek J P and Hijnen W A M, Water Supply., 1992, 10(3), 91-100.

66. Nilsson I and Ohlson S, Eur J Appl Microbiol Biotechnol., 1982, 14, 86-90.

67. McCleaf P R and Schroeder E D, J AWWA, 1995, 87(3), 77-86.

68. Roising A. R and Schroeder E D, J Environ Eng ASCE, 1996, 122(7), 599-604.

69. Claus Günter and Hans Jürgen Kutzner, Appl Microbiol Biotechnol., 1985, 22(4), 289-296.

70. Schippers J C, Kruithof J C, Mulder F G and van Lieshout J W, Aqua, 1987, 5, 274-280.

71. Lewandowski Z, Bakke R and Characklis W G, Wat Sci Tech., 1987, 19, 175-182.

72. Gross H and Treuter K, Aqua, 1986, 5, 288-290. 


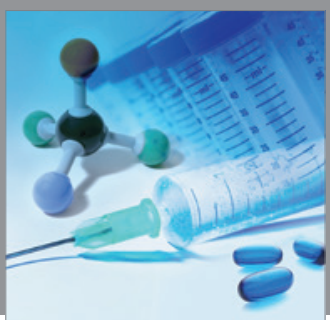

International Journal of

Medicinal Chemistry

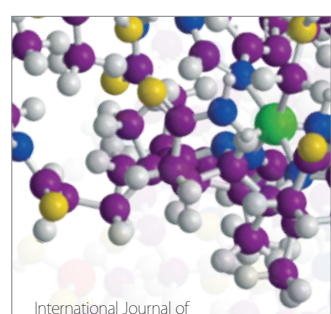

Carbohydrate Chemistry

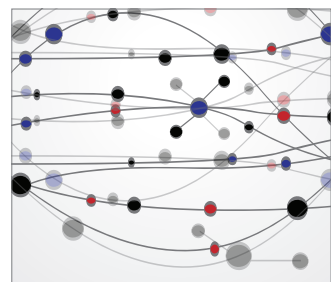

The Scientific World Journal
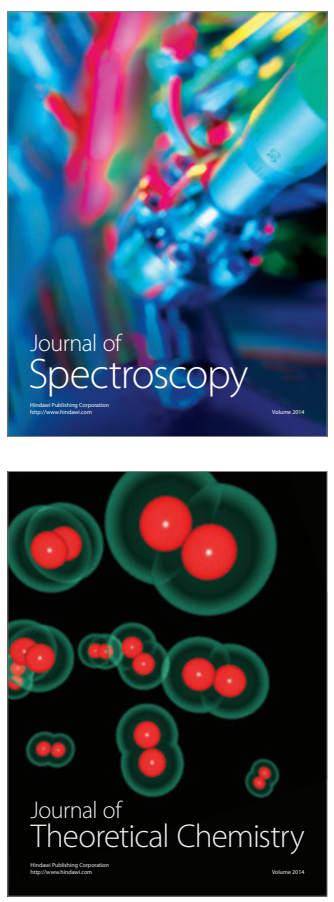
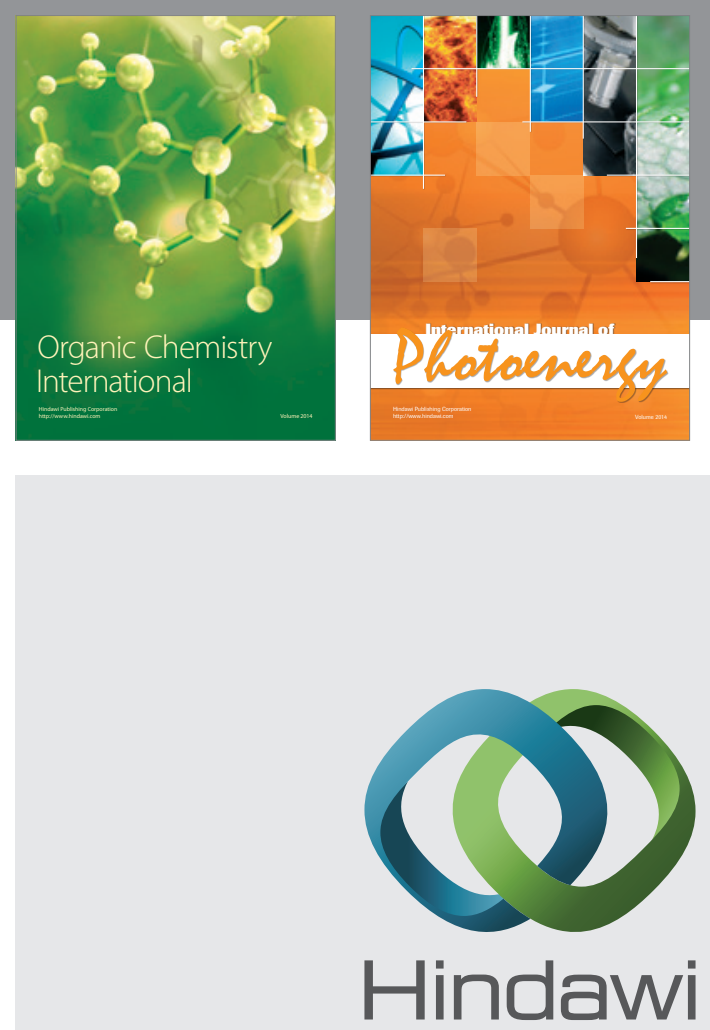

Submit your manuscripts at

http://www.hindawi.com
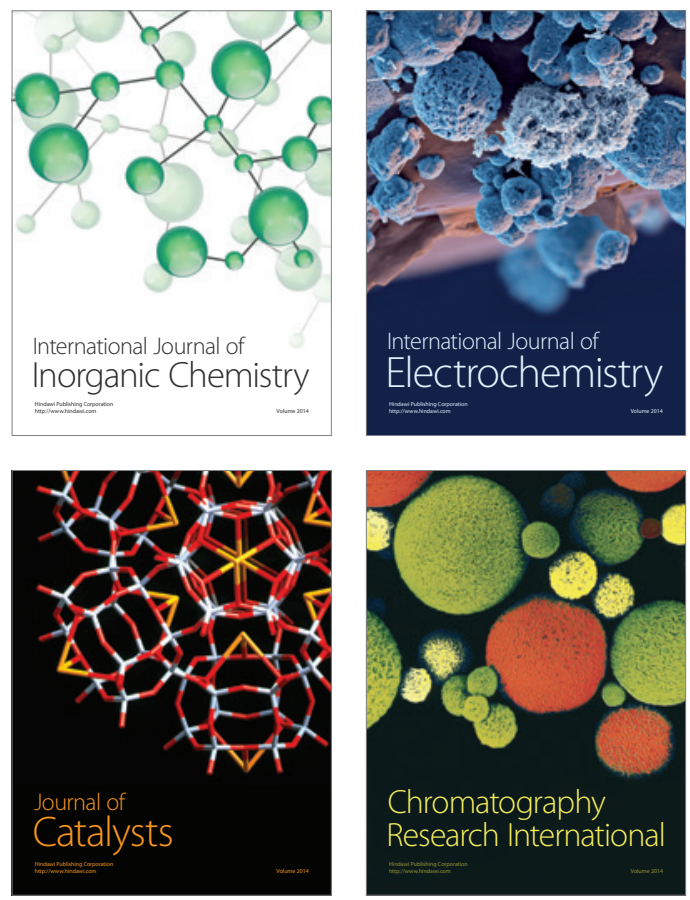
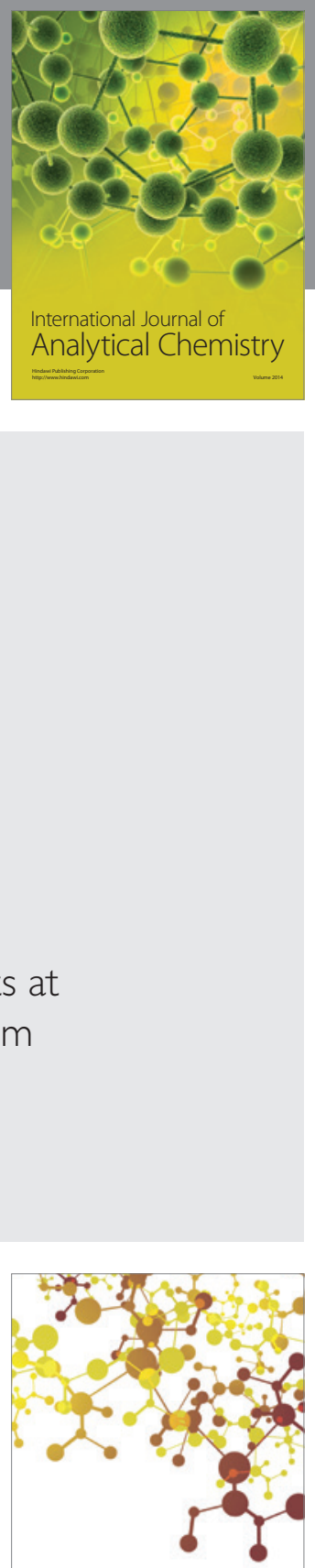

Journal of

Applied Chemistry
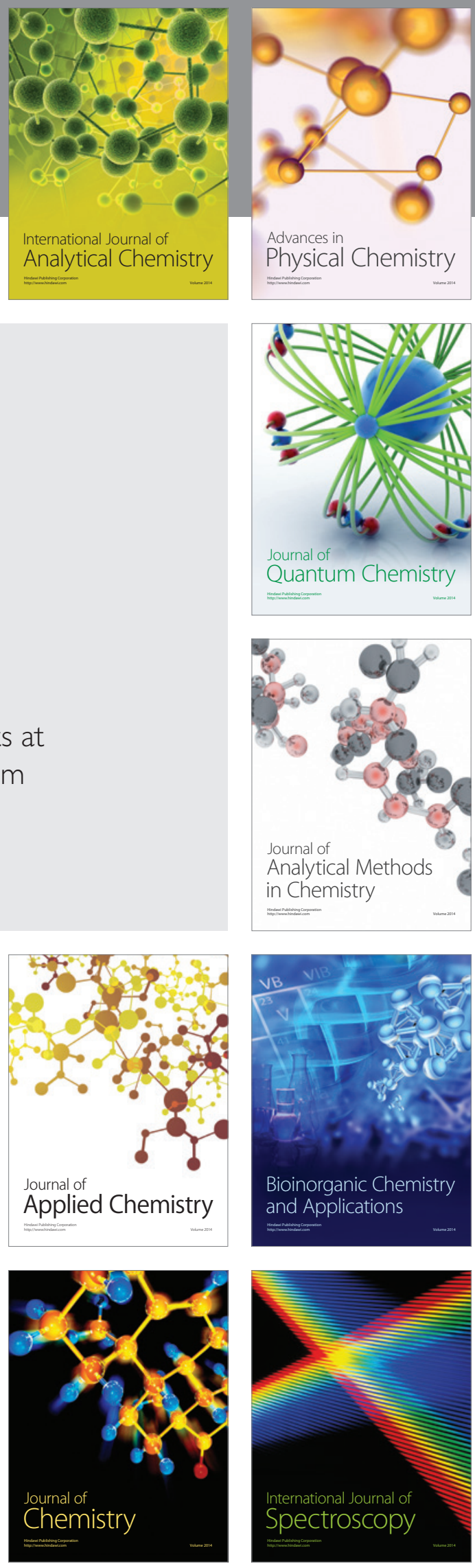